\title{
Phytochemistry and In vitro Antimicrobial Activity of Five Plant Species against Nine Common Human Pathogens
}

\section{Olufunmilayo Adejumo ${ }^{1}$, Ike Williams ${ }^{2}$, Kehinde Ojewale ${ }^{1}$, Christopher Igbokwe $^{3}$ and Ibironke Ajayi ${ }^{4}$}

\author{
${ }^{1}$ Department of Pharmaceutical and Medicinal Chemistry, Olabisi Onabanjo University, Sagamu, Nigeria \\ ${ }^{2}$ Department of Microbiology, Federal University of Agriculture, Abeokuta, Nigeria \\ ${ }^{3}$ Department of Pharmaceutical Microbiology, University of Ibadan, Ibadan, Nigeria \\ ${ }^{4}$ Department of Chemistry, University of Ibadan, Ibadan, Nigeria
}

(Received: October 14, 2020; Accepted: June 22, 2021; Published (web): June 29 2021)

\begin{abstract}
Momordica charantia, Senna podocarpa, Senna alata, Ocimum gratissimum, and Sida acuta which have reportedly been used in folklore for the treatment of various diseases were studied for their antimicrobial activity. Crude methanolic extracts of the leaves were screened for phytochemicals after which they were tested in vitro for activity against clinical isolates of Staphylococcus aureus, Klebsiella oxytoca, Pseudomonas aeruginosa, Proteus vulgaris, Bacillus subtilis, Enterobacter aerogenes, Aspergillus niger, A, flavus and Candida albicans. Phytochemicals present in the extracts included saponins, alkaloids, anthraquinones, tannins, flavonoids and cardiac glycosides. These extracts also showed varying degrees of activity against tested organisms at a concentration range of 15.6 to $500 \mathrm{mg} / \mathrm{ml}$. However, S. acuta showed activity against $P$. vulgaris, E. aerogenes and As. flavus only. The MIC of the extracts against test organisms ranged from 31.25 to $250 \mathrm{mg} / \mathrm{ml}$. The significant antimicrobial susceptibility of the plant extracts against gram positive bacterial pathogens and some pathogenic yeasts, may not be due to the presence and synergistic interactions of secondary metabolites found in these plant extracts. This would have implications in health, particularly in developing countries where a singnificant percentage of the population are still using traditional plant extracts for health care.
\end{abstract}

Key words: Phytochemicals, in vitro, antimicrobial activity, human pathogens, plant species

\section{INTRODUCTION}

Man had from time immemorial, met his medical needs through the use of herbs and herbal products ${ }^{1}$ before the advent of orthodox medicine. Hence, plant-derived medicines remain an important resource to combat various illnesses, including infectious diseases ${ }^{2}$; especially in some parts of primary health care. Plants have been studied and reported to provide sources of inspiration for novel drug compounds. Their extracts are useful alternative antimicrobial substances. ${ }^{3}$ The current emergence of antimicrobial-resistant strains around the globe has necessitated the return of natural plants products in the treatment of infections caused by microbes. ${ }^{4}$

Correspondence to: Olufunmilayo Adejumo Email: funmijumo@yahoo.co.uk; Tel.: +234-805-270-5549

Dhaka Univ. J. Pharm. Sci. 20(2): 139-148, 2021 (December) DOI: https://doi.org/10.3329/dujps.v20i2.57164
The World Health Organization (WHO) has put the world population that depends on medicinal plants for their health care needs at about $80 \%$ and more than $30 \%$ of the pharmaceutical preparations are based on plants. ${ }^{5}$ Also, the WHO has reported cases of changing sensitivities of various bacteria to antibiotics $^{6}$ aside from a global challenge of the emergence of multidrug-resistant pathogens. ${ }^{7}$ Antimicrobial resistance undermines our ability to fight infectious diseases and poses serious health issues in hospitals, care centres and communities such as increased cost of health care and length of stay. ${ }^{8}$ Additionally, many patients prefer herbal remedies to treat diseases due to the side effects and untoward effects of some chemical and orthodox drugs. $^{9}$

M. charantia (Cucurbitaceae) commonly called bitter lemon or wild cucumber has been reported to be an effective therapeutic agent against diabetes, 
menstrual troubles, syphilis, rheumatism, boils and ulcers $^{10}$. Anticancer, anti-oxidant, anthelmintic, antimalarial, antiviral and antimicrobial properties of the plant are also found in literature/ ${ }^{2,11-14}$ Protein MAP-30, alpha-momorcharin and beta-momorcharin with anti-HIV activity ${ }^{15}$ and a steroid, charantin, with proven antidiabetic activity ${ }^{16}$ are some compounds that have been isolated from $M$. charantia.

$S$. podocarpa (Ceasalpiniaceae) is a laxative, having anti-gonorrhoeal, and purgative properties. Additionally, it has been used as guinea-worm and sore-healing remedy among the Igbos of South-East Nigeria. ${ }^{17}$ S. alata, of the same family, has been used as an anti-fungicidal agent in the treatment of skin disorders caused by dermatocytes. ${ }^{18}$ Similarly, $O$. gratissimum (Labiatae) leaf, has been found useful in the treatment of diarrhoea, headache and bronchitis while S. acuta (Malvaceae) leaf was reported in the treatment of catarrh, dysentery, nephritis and convulsion. ${ }^{19}$

It has been reported in the literature that medicinal plant species have great antimicrobial and antifungal activities on common pathogens. ${ }^{20,21}$ The crude methanol extract of Allium ascolonicum has been reported to show significant activity against nosocomial pathogens such as $S$. aureus, $P$. aeruginosa, and $C$. albicans, some of which was used in this study. ${ }^{22} \mathrm{~K}$. oxytoca, an opportunistic pathogen that has been implicated in septic shock in humans has also been reported to show susceptibility to crude extract of Allium ascolonicum..$^{22,23}$

B. subtilis plays a primary role in the development of the gut-associated lymphoid tissue (GALT) and the pre-immune antibody repertoire in the rabbit. ${ }^{24}$ Though not generally considered pathogenic, B. subtilis can be leveraged to reach the very pathogenic members of the genus Bacillus such as B. anthracis, since they share genomic similarities.

Enterobacter cloacae and E. aerogenes are often implicated in bacteraemia cases. ${ }^{25}$ Aspergillus flavus is second to A. fumigatus as the cause of human invasive Aspergillosis and additionally the major species of Aspergillus that infect insects. ${ }^{26-28}$
A. niger is one of the most common causes of Otomycosis, which can cause pain, temporary hearing loss, and in severe cases, damage to the ear canal and tympanic membrane. ${ }^{29}$ Previous evaluation of the antimicrobial properties of the ethanolic extracts of some medicinal plant seeds from SouthWest Nigeria has been reported ${ }^{30}$ but the literature on the phytochemicals of the five plant species in our study and antimicrobial activity is scanty. This study is therefore designed to screen the extracts of five plants-species for phytochemical constituents and then evaluate their activities against common human pathogens (six bacterial and three fungal) providing a scientific basis for some of their folkloric uses. This is geared towards advancing our studies to bring into the limelight some lesser-known medicinal plant species that have folkloric uses ${ }^{30,31}$ to discover if these plants could serve as potential sources of new antimicrobial agents.

\section{MATERIALS AND METHODS}

Plant collection and processing. Five plants belonging to different families (Table 2) were selected based on their traditional usage for the treatment of infectious diseases. The plant species were collected from various parts of Ogun State, South-West, Nigeria. They were identified and authenticated by $\mathrm{Mr}$ Adeyemo at the herbarium in Forest Research Institute of Nigeria (FRIN), Ibadan, Nigeria. Voucher specimens were deposited for reference purposes, with the voucher numbers FHI. 111052, FHI. 111053, FHI. 111054, 111770 and 111805 for Momordica charantia (Cucurbitaceae), Ocimum gratissimum (Labiatae), Sida acuta (Malvaceae), Senna alata (Ceasalpiniaceae) and Senna podocarpa (Ceasalpiniaceae), respectively.

The plant materials were processed by airdrying, and pulverization before Soxhlet extraction, allowing for a combination of percolation and immersion techniques. Various yields of extracts were obtained from the plants-materials using methanol as solvent. The extracts were filtered and 
concentrated in vitro, using a rotary evaporator at $4^{\circ} \mathrm{C}$.

Microorganisms. Clinical isolates of six common human pathogenic bacteria and three fungi species were included in this study namely Pseudomonas aeruginosa, Bacillus subtilis, Staphylococcus aureus, Klebsiella oxytoca, Proteus vulgaris, Enterobacter aerogenes, Aspergillus niger, A. flavus and Candida albicans (Table 1). These clinical isolates were identified using standard microbiological and biochemical procedures.

Screening for phytochemicals. Qualitative analysis of the methanolic extracts of the plants for phytochemicals such as alkaloids, saponins, tannins, flavonoids, anthraquinone and cardiac glycosides was carried out in accordance with Trease and Evans ${ }^{32}$ and Harborne ${ }^{33}$ with little modification.

Susceptibility testing. The agar diffusion method was used for the antimicrobial susceptibility testing of the plant extracts ${ }^{34}$. Only $0.2 \mathrm{ml}$ of one in hundred dilutions of a fresh overnight culture of the respective test organisms were seeded into $20 \mathrm{ml}$ of molten Mueller-Hinton agar at $45^{\circ} \mathrm{C}$ for bacterial species and Saboraud dextrose agar (SDA), for fungal species. These were properly blended while still molten in a universal bottle and poured aseptically into Petri dishes. The plates were allowed to set before using a sterile $6 \mathrm{~mm}$ diameter cork borer to bore equidistant wells on the dry agar plates. Various concentrations, ranging between 7.8 to 500 $\mathrm{mg} / \mathrm{ml}$ of the extracts, were introduced into their respective wells as labelled. For positive control, ciprofloxacin and clotrimazole were placed in their respective wells. The plates were allowed to stand on the bench for 1 hour to allow for the extracts to diffuse into the agar, before incubation at $37^{\circ} \mathrm{C}$ for 24 hours for bacterial species and $25^{\circ} \mathrm{C}$ for 48 hours for fungal species. After incubation, the zones of inhibition were measured with a transparent metre rule.

Determination of minimum inhibitory concentration (MIC). MIC of the extracts was determined by a previous method. ${ }^{35}$ An aliquot of 1 $\mathrm{ml}$ of different concentrations of each extract (500, $250,125,62.5,31.2,15.6$ and $7.8 \mathrm{mg} / \mathrm{ml}$ ) was added to $19 \mathrm{ml}$ of molten Mueller-Hinton agar. The mixture was properly homogenized before pouring into sterile Petri-dishes. The Petri-dishes were then allowed to set and dried before streaking with an overnight culture of the test organisms. The Petri-dishes were incubated for 24 to 48 hours at $37{ }^{\circ} \mathrm{C}$ and $25{ }^{\circ} \mathrm{C}$ for bacterial and fungal species, respectively. All the tests were performed in duplicates.

\section{RESULTS AND DISCUSSION}

Extraction yield of plants and organisms. Five plants from various sources (Table 1) belonged to different families were selected based on their traditional usage for the treatment of infectious diseases. Each of the plants was extracted with methanol and gave a percentage yield of 24.6, 45.5, 35.6, 43.7 and $33.0 \% \mathrm{w} / \mathrm{v}$ for $M$. charantia, $S$. podocarpa, S. alata, S. acuta and O. Gratissimum, respectively. The five plants were investigated against

Table 1. Clinical sources of isolates and diagnosis.

\begin{tabular}{lll}
\hline Isolates & Clinical source & Diagnosis \\
\hline Pseudomonas aeruginosa & Biopsy & Folliculitis \\
Bacillus subtilis & Wound & Allergy \\
Staphylococcus aureus & Wound & Cellulitis \\
Klebsiella oxytoca & Urine & Urethritis \\
Proteus vulgaris & Stool & Diarrhoea \\
Enterobacter aerogenes & Urine & Urethritis \\
Aspergillus niger & Ear discharge & Otomycosis \\
Aspergillus flavus & Sputum & Pulmonary fibrosis \\
Candida albicans & Vaginal discharge & Candidiasis \\
\hline
\end{tabular}


nine clinical isolates, including two Gram-positive bacteria (Bacillus subtilis and Staphylococcus aureus), four Gram-negative bacteria (Pseudomonas aeruginosa, Klebsiella oxytoca, Proteus vulgaris, and Enterobacter aerogenes), and three fungi species (Aspergillus niger, A. flavus, Candida albicans). All the isolates were identified using standard microbiological and biochemical procedures.

Phytochemical screening. Screening for phytochemicals in the plant extracts revealed the presence of bioactive constituents such as saponins, tannins (polyphenols) and flavonoids in S. alata and S. podocarpa extracts as shown in Table 2 .

Table 2. Screening for phytochemicals in the plant extracts.

\begin{tabular}{|c|c|c|c|c|c|c|}
\hline $\mathrm{S} / \mathrm{N}$ & Secondary metabolites & Momordica charantia & Senna podocarpa & Senna alata & Sida acuta & Ocimum gratissimum \\
\hline 1. & Alkaloids & + & - & - & - & + \\
\hline 2. & Anthraquinone & - & - & + & - & - \\
\hline 3. & Saponins & - & + & + & + & + \\
\hline 4. & Tannins & - & + & + & - & - \\
\hline 5. & Cardiac Glycosides & - & - & - & + & - \\
\hline 6. & Cyanogenetic glycosides & - & - & - & - & - \\
\hline 7. & Flavonoids & - & + & + & - & - \\
\hline
\end{tabular}

Note: + = Present; - = Absent

Antibacterial and antifungal activities of five plant species. The extracts of $M$. charantia, S. alata, and $O$. gratissimum exhibited a broad antibacterial and antifungal spectrum against the bacterial and fungal species tested. Extracts of S. podocarpa, and $O$. gratissimum only displayed antibacterial activity against $P$. aeruginosa with an MIC value of 31.25 $\mathrm{mg} / \mathrm{ml}$ each but that of $M$. charantia was active against $P$. aeruginosa and also $B$. subtilis, $S$. aureus and $K$. oxytoca with a MIC values of $31.25,15.625$, 62.5 and $125 \mathrm{mg} / \mathrm{ml}$, respectively. This made $B$. subtilis the most susceptible, while organisms such as $P$. vulgaris and $E$. aerogenes were resistant to the tested plant extracts. However, there was slight activity against the fungal species.

Tannins are generally defined as naturally occurring polyphenolic compounds, which have been implicated in playing an important role in tissue protection for plants ${ }^{36}$. They are known antioxidants that reduce oxidative damage to cells due to their strong free radicals quenching property ${ }^{37}$ aside from providing protection from a number of immune/autoimmune, cardiovascular and other diseases. ${ }^{38}$ In addition, S. alata extract also contained anthraquinones; a chemical group that has been implicated as a purgative and laxative. This result tends to correlate with the local usage of $S$. alata plant species in the treatment of gastrointestinal disorders. Senna alata belongs to the family Fabaceae,-which have shown anti-tumors, laxative, emetic, astringent, antipyretic and antioxidant properties. ${ }^{39}$

S. alata is distributed in many South American countries such as northern Brazil, Colombia, Venezuela, and the Guyanas. The antimicrobial activity of the plants has been linked with the presence of some chemical components such as tannins, saponins, phenols, alkaloids, steroids, flavonoids and carbohydrates. ${ }^{40}$ Chrysophanic acid, which is reported to have activity against skin pathogens have been identified in the leaf of this plant; hence its use in the treatment of skin infections ${ }^{41}$. The secondary metabolites that were discovered in $S$. acuta is saponins and cardiac glycosides while $O$. gratissimum contained alkaloids and saponins but alkaloids were the only bioactive constituent that was present in M. charantia. These phytochemicals possibly account for the 
antimicrobial activity of the plants against some of the tested pathogens.

Our observations are slightly different from those of Costa et al. ${ }^{42}$ where phytochemical analysis of the fresh and dried leaves extracts of $M$. charantia showed the presence of flavonoids, alkaloids and tannins that were reported to demonstrate antimicrobial action. Extracts in their study showed significant antimicrobial activity against all bacterial strains tested, especially Escherichia coli and Bacillus cereus ${ }^{42}$. Omoregbe et al..$^{43}$ had also reported the antimicrobial activity of aqueous, ethanolic and methanolic extracts of $M$. charantia leaves against $E$. coli, Salmonella paratyphi, Shigella dysenterae, Streptomyces griseus and Mycobacterium tuberculosis; organisms different from those used in this study. The activity of $M$. charantia may be due to the presence of alkaloids. Its broad-spectrum antimicrobial activity justifies its use in the treatment of a good number of infections as well as a laxative, and appetite stimulant. It is also used in the treatment of gastrointestinal infections and to lower blood sugar in diabetics. Additionally, it has been found to be effective in the treatment of certain types of cancer and viral infections. ${ }^{44}$

M. charantia, S. alata, O. gratissimum and $S$. acuta were the only plant extracts that exhibited activity against fungal species with varied degree of MIC values while $S$. podocarpa extract showed activity against bacterial strains only with MIC values of $31.25 \mathrm{mg} / \mathrm{ml}$ for $P$. aeruginosa and 500 $\mathrm{mg} / \mathrm{ml}$ for $S$. aureus. The alkaloids, saponins, tannins (polyphenols) in S. podocarpa are suspected to be responsible for the antimicrobial activity of the plant. ${ }^{45}$ Phenolic compounds exist naturally in plants and vegetables and have the ability to scavenge free radicals directly by donating a hydrogen atom and chelate metal ions or indirectly by upregulating antioxidant enzymes through their effects on the pathways of cell-signalling and gene expression. ${ }^{46-48}$

Pharmacologically, this mechanism might also support the antimicrobial activity of this class of compounds since polyphenols also possess antimicrobial activity. ${ }^{49}$ They are known to form heavy soluble complexes with protein. Polyphenols react with the protein moiety of the enzyme and cause inhibition of cAMP-dependent protein kinase activity. These substances also attack the bacterial cell wall, binding to it by adhesion and consequently disrupting the availability of receptors on the cell surface. This plausibly explains the observed broadspectrum activity of this plant extract against the tested organisms. The stereoelectronic effect of the phenyl group is a major contributing factor for antimicrobial activity. ${ }^{50}$

Our observations are in agreement with some previous studies which reported that various plant extracts such as that of Sideritis ozturk and $S$. caesarea possesses significant antimicrobial activity $^{51}$, while good activity against $S$. aureus was shown for hexane extract of $S$. scardica ${ }^{52}$ With the exception of $S$. acuta, all the plant extracts tested demonstrated impressive anti-bacterial efficacies against Gram-positive strains with MIC values $\leq$ $250 \mathrm{mg} / \mathrm{ml}$. In particular, the extract of $M$. charantia against $B$. subtilis showed potent antibacterial activity with a MIC value of $15.625 \mathrm{mg} / \mathrm{ml}$. Similarly, high activity was recorded for the extract of $S$. alata against $S$. aureus with the same MIC value of 15.625 $\mathrm{mg} / \mathrm{ml}$. However, it is worthy of note that $S$. alata showed the strongest antifungal activity against fungi species tested with a MIC value of $7.8125 \mathrm{mg} / \mathrm{ml}$. Senna alata belongs to the family, Fabaceae. Many species of Senna have shown anti-tumor, laxative, emetic, astringent, antipyretic and antioxidant properties. ${ }^{39}$

The antimicrobial activity of the plant has been linked with the presence of some chemical components such as tannins, saponins, phenols, alkaloids, steroids, flavonoids and carbohydrates. ${ }^{40}$ On the other hand, ciprofloxacin and clotrimazole used as positive control showed preferential activity; whereas ciprofloxacin demonstrated activity against bacteria strains, clotrimazole showed activity against fungi species.

In contrast, the antibacterial activity against Gram-negative bacteria strains were exhibited only by some of the extracts. Results obtained in this study 
showed that the Gram-negative strains were more resistant to the plant extracts than the Gram-positive strains. For instance, strains such as $P$. vulgaris and E. aerogenes were resistant to $M$. charantia extract at a MIC of $500 \mathrm{mg} / \mathrm{ml}$. Similarly, high resistance was recorded also for $P$. aeruginosa against $S$. alata and S. acuta extracts at MIC of $500 \mathrm{mg} / \mathrm{ml}$. On the contrary, $S$. acuta extract showed activity against $P$. vulgaris and $E$. aerogenes at MIC of 15.625 and 125 $\mathrm{mg} / \mathrm{ml}$, respectively.

Table 3. Results of the antimicrobial screening of methanol extracts of plant species.

\begin{tabular}{|c|c|c|c|c|c|c|c|c|c|c|}
\hline \multirow[b]{2}{*}{ Extracts } & \multirow[b]{2}{*}{$\begin{array}{l}\text { Conc. } \\
(\mathrm{mg} / \mathrm{ml})\end{array}$} & \multicolumn{9}{|c|}{ Diameter zone of inhibition (in $\mathrm{mm}) \pm$ SEM } \\
\hline & & $\begin{array}{c}P . \\
\text { aeruginosa }\end{array}$ & B. subtilis & S. aureus & K. oxytoca & $\begin{array}{c}P . \\
\text { vulgaris }\end{array}$ & $\begin{array}{c}E . \\
\text { aerogenes }\end{array}$ & $\begin{array}{c}C . \\
\text { albicans }\end{array}$ & A. niger & A. flavus \\
\hline \multirow[t]{7}{*}{ M. charantia } & 500 & $16.5 \pm 0.2$ & $18.2 \pm 0.0$ & $17.1 \pm 0.5$ & $19.2 \pm 0.2$ & - & - & $18.0 \pm 0.5$ & $25.0 \pm 0.4$ & - \\
\hline & 250 & $13.2 \pm 0.0$ & $18.0 \pm 0.2$ & $16.0 \pm 0.2$ & $17.1 \pm 0.2$ & - & - & $15.0 \pm 0.2$ & $22.0 \pm 0.2$ & - \\
\hline & 125 & $12.3 \pm 0.1$ & $16.7 \pm 0.0$ & $15.2 \pm 0.0$ & $16.4 \pm 0.4$ & - & - & $10.0 \pm 0.0$ & $19.0 \pm 0.2$ & - \\
\hline & 62.5 & $10.4 \pm 0.1$ & $14.1 \pm 0.4$ & $10.7 \pm 0.2$ & - & - & - & - & $10.0 \pm 0.2$ & - \\
\hline & 31.25 & $10.0 \pm 0.2$ & $13.6 \pm 0.0$ & - & - & - & - & - & - & - \\
\hline & 15.625 & - & $12.4 \pm 0.0$ & - & - & - & - & - & - & - \\
\hline & 7.8125 & - & - & - & - & - & - & - & - & - \\
\hline \multirow[t]{7}{*}{ S. podocarpa } & 500 & $21.5 \pm 0.4$ & $22.5 \pm 0.2$ & $30.02 \pm 0.4$ & - & $12.0 \pm 0.2$ & $15.6 \pm 0.2$ & - & - & - \\
\hline & 250 & $12.0 \pm 0.2$ & $18.5 \pm 0.3$ & $26.5 \pm 0.2$ & - & $10.0 \pm 0.0$ & $14.2 \pm 0.0$ & - & - & - \\
\hline & 125 & $11.0 \pm 0.0$ & $17.0 \pm 0.2$ & $21.0 \pm 0.2$ & - & - & $12.0 \pm 0.0$ & - & - & - \\
\hline & 62.5 & $10.0 \pm 0.0$ & $11.0 \pm 0.2$ & $18.5 \pm 0.2$ & - & - & $10.2 \pm 0.0$ & - & - & - \\
\hline & 31.25 & $10.0 \pm 0.0$ & - & $15.0 \pm 0.0$ & - & - & - & - & - & - \\
\hline & 15.625 & - & - & - & - & - & - & - & - & - \\
\hline & 7.8125 & - & - & - & - & - & - & - & - & - \\
\hline \multirow[t]{7}{*}{ S. alata } & 500 & - & $17.9 \pm 0.0$ & $16.3 \pm 0.0$ & - & $16.4 \pm 0.2$ & $14.8 \pm 0.0$ & $40.0 \pm 0.2$ & $74.0 \pm 0.0$ & $69.0 \pm 0.2$ \\
\hline & 250 & - & $17.0 \pm 0.0$ & $15.7 \pm 0.0$ & - & $15.9 \pm 0.4$ & $14.2 \pm 0.0$ & $30.0 \pm 0.4$ & $50.0 \pm 0.0$ & $60.0 \pm 0.2$ \\
\hline & 125 & - & $16.5 \pm 0.0$ & $15.2 \pm 0.0$ & - & $14.1 \pm 0.2$ & $13.0 \pm 0.0$ & $26.0 \pm 0.2$ & $40.0 \pm 0.2$ & $44.0 \pm 0.4$ \\
\hline & 62.5 & - & $15.8 \pm 0.0$ & $14.8 \pm 0.0$ & - & $12.0 \pm 0.0$ & $12.8 \pm 0.0$ & $20.0 \pm 0.2$ & $38.0 \pm 0.2$ & $40.0 \pm 0.2$ \\
\hline & 31.25 & - & $15.0 \pm 0.0$ & $14.2 \pm 0.0$ & - & $11.8 \pm 0.0$ & - & $18.0 \pm 0.4$ & $36.0 \pm 0.0$ & $30.0 \pm 0.0$ \\
\hline & 15.625 & - & - & $13.0 \pm 0.0$ & - & - & - & $15.0 \pm 0.2$ & $30.0 \pm 0.0$ & $28.0 \pm 0.2$ \\
\hline & 7.8125 & - & - & - & - & - & - & $14.0 \pm 0.2$ & $28.0 \pm 0.0$ & $20.0 \pm 0.2$ \\
\hline \multirow{7}{*}{$\begin{array}{l}\text { O. } \\
\text { gratissimum }\end{array}$} & 500 & $15.8 \pm 0.0$ & $15.5 \pm 0.0$ & $10.6 \pm 0.0$ & $14.2 \pm 0.0$ & - & - & $35.0 \pm 0.0$ & - & $38.0 \pm 0.2$ \\
\hline & 250 & $15.6 \pm 0.0$ & $14.9 \pm 0.0$ & $10.0 \pm 0.0$ & $12.8 \pm 0.0$ & - & - & $30.0 \pm 0.0$ & - & $28.0 \pm 0.0$ \\
\hline & 125 & $15.0 \pm 0.0$ & $14.2 \pm 0.0$ & - & $12.6 \pm 0.0$ & - & - & $25.0 \pm 0.0$ & - & $26.0 \pm 0.0$ \\
\hline & 62.5 & $14.9 \pm 0.0$ & $12.7 \pm 0.0$ & - & $12.0 \pm 0.0$ & - & - & $22.0 \pm 0.0$ & - & $20.0 \pm 0.0$ \\
\hline & 31.25 & $14.0 \pm 0.0$ & - & - & - & - & - & $18.0 \pm 0.0$ & - & $15.0 \pm 0.0$ \\
\hline & 15.625 & - & - & - & - & - & - & $12.0 \pm 0.0$ & - & $12.0 \pm 0.0$ \\
\hline & 7.8125 & - & - & - & - & - & - & - & - & - \\
\hline \multirow[t]{7}{*}{ S. acuta } & 500 & - & - & - & - & $17.6 \pm 0.2$ & $15.9 \pm 0.50$ & - & - & $18.1 \pm 0.2$ \\
\hline & 250 & - & - & - & - & $17.2 \pm 0.00$ & $15.4 \pm 0.20$ & - & - & $15.1 \pm 0.5$ \\
\hline & 125 & - & - & - & - & $16.8 \pm 0.3$ & $15.0 \pm 0.00$ & - & - & $10.0 \pm 0.2$ \\
\hline & 62.5 & - & - & - & - & $15.0 \pm 0.2$ & - & - & - & - \\
\hline & 31.25 & - & - & - & - & $14.0 \pm 0.0$ & - & - & - & - \\
\hline & 15.625 & - & - & - & - & $12.0 \pm 0.0$ & - & - & - & - \\
\hline & 7.8125 & - & - & - & - & - & - & - & - & - \\
\hline \multirow{6}{*}{$\begin{array}{l}\text { Ciprofloxacin } \\
(U S P)\end{array}$} & 50 & $22.0 \pm 0.0$ & $19.0 \pm 0.0$ & $23.0 \pm 0.2$ & $20.0 \pm 0.0$ & $25.0 \pm 0.0$ & $20.0 \pm 0.0$ & & & \\
\hline & 25 & $21.0 \pm 0.0$ & $15.0 \pm 0.0$ & $22.0 \pm 0.0$ & $18.0 \pm 0.0$ & $22.0 \pm 0.0$ & $15.0 \pm 0.0$ & & & \\
\hline & 12.5 & $19.0 \pm 0.1$ & $12.0 \pm 0.0$ & $15.0 \pm 0.0$ & $15.0 \pm 0.0$ & $21.0 \pm 0.0$ & $12.0 \pm 0.0$ & & & \\
\hline & 6.25 & $16.0 \pm 0.2$ & - & $12.0 \pm 0.0$ & $12.0 \pm 0.0$ & $20.0 \pm 0.0$ & $10.0 \pm 0.0$ & & & \\
\hline & 3.125 & $12.0 \pm 0.2$ & - & - & - & $17.0 \pm 0.0$ & - & & & \\
\hline & 1.5625 & - & - & - & - & $12.0 \pm 0.0$ & - & & & \\
\hline \multirow{6}{*}{$\begin{array}{l}\text { Clotrimazole } \\
(B P)\end{array}$} & 50 & & & & & & & $26.0 \pm 0.0$ & $22.0 \pm 0.0$ & $24.0 \pm 0.0$ \\
\hline & 25 & & & & & & & $20.0 \pm 0.0$ & $18.0 \pm 0.0$ & $20.0 \pm 0.0$ \\
\hline & 12.5 & & & & & & & $18.0 \pm 0.0$ & $12.0 \pm 0.0$ & $18.0 \pm 0.0$ \\
\hline & 6.25 & & & & & & & $16.0 \pm 0.0$ & - & $17.0 \pm 0.0$ \\
\hline & 3.125 & & & & & & & $14.0 \pm 0.0$ & - & $10.0 \pm 0.0$ \\
\hline & 1.5625 & & & & & & & $10.0 \pm 0.0$ & - & - \\
\hline
\end{tabular}

Diameter of cork borer $=6 \mathrm{~mm}$; Results are average of duplicate experiments. 
Table 4. Minimum inhibitory concentration (mic) of the plant extracts on test organisms.

\begin{tabular}{lccccccccc}
\hline \multicolumn{10}{c}{ MIC values in $\mathrm{mg} / \mathrm{ml}$ of the organisms } \\
\hline Extracts & P. aeruginosa & B. subtilis & S. aureus & K. oxytoca & P. vulgaris & E. aerogenes & C. albicans & A. niger & A. flavus \\
\hline M. charantia & 31.25 & 15.63 & 62.50 & 125.00 & NA & NA & ND & ND & ND \\
S. podocarpa & 31.25 & 62.50 & 31.25 & NA & 250.00 & 31.25 & ND & ND & ND \\
S. alata & NA & 31.25 & 15.63 & NA & 31.25 & 62.5 & ND & ND & ND \\
O. gratissimum & 31.25 & 62.50 & 250.00 & 31.25 & NA & NA & ND & ND & ND \\
S. acuta & NA & NA & NA & NA & 15.63 & 125.00 & ND & ND & ND \\
\hline
\end{tabular}

$\mathrm{NA}=$ Not Active; $\mathrm{ND}=$ Not determined.

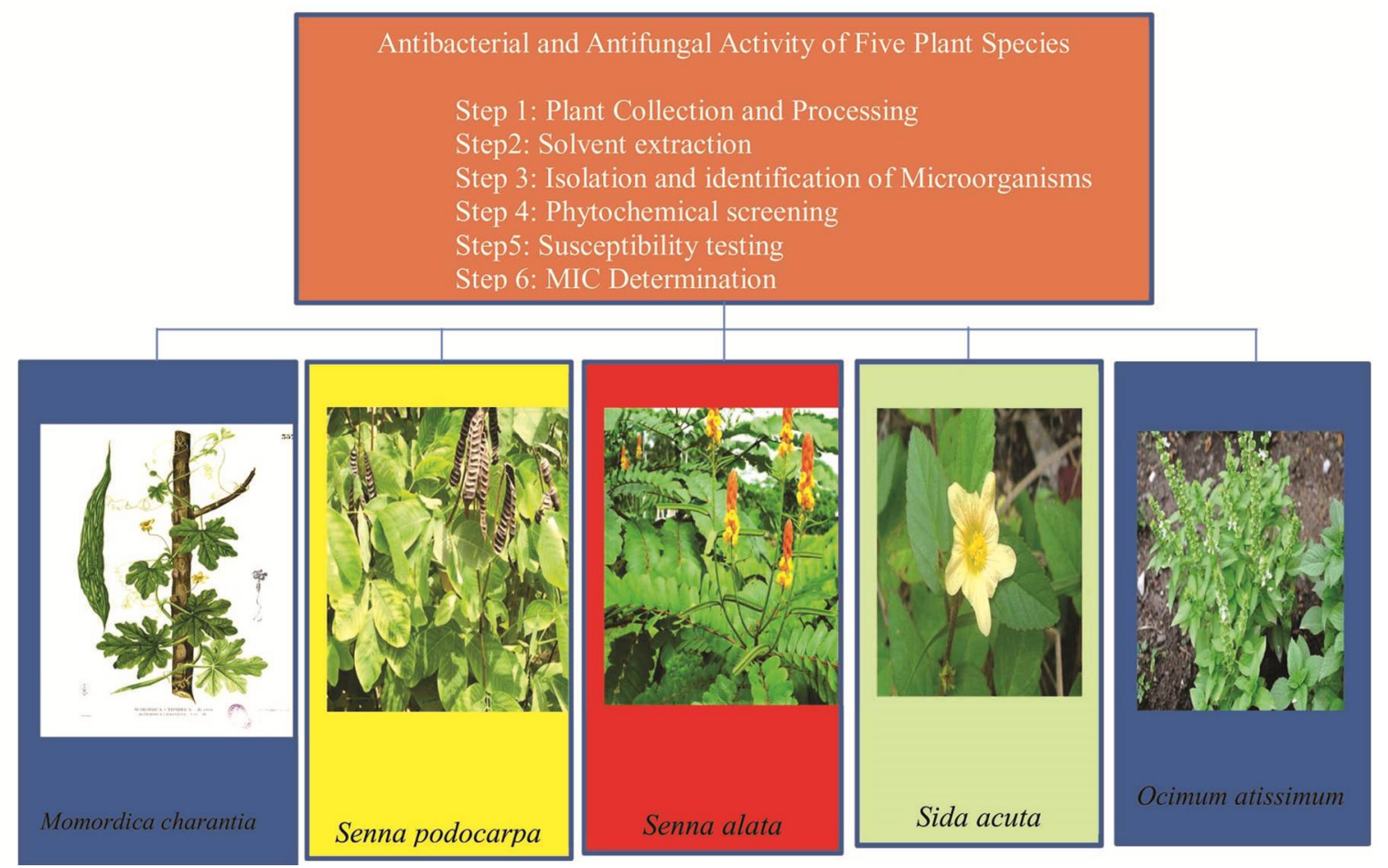

Figure 1. Study steps and pictures of five plant species [55] (pictures used with permission)

Previous studies have also demonstrated that medicinal plant species have great antimicrobial and antifungal activities on common pathogens..$^{20,21}$ Most reports from previous studies used different methods or bacterial species, which plausibly explain the differences observed in our study when compared with the data found in existing literature. Similarly, such contrasting results where they exist might be largely attributed to the different locations where the plants were collected from and the solvent used in the extraction. However, this study has shown that plant derived extracts have antimicrobial effects with the potential to curb current instances of antimicrobial resistance to orthodox medicines. Consequently, more emphasis should be placed on further investigation of these plants to derive natural sources of antimicrobials, compounds that could potentially replace or augment synthetic antimicrobial agents. ${ }^{53,54}$ Graphical figure 1 shows the stepwise organogram of the study. ${ }^{55}$

\section{CONCLUSION}

The findings from this research support the use of these plant species in folk medicine. These are confirmed by the in-vivo antimicrobial studies on the 
plant extracts corroborating their usage as part of the treatment for infectious diseases caused by these pathogens. Further research needs to be carried out to isolate and purify the biologically active components from these extracts.

\section{ACKNOWLEDGEMENTS}

The authors would like to thank Mr Ndimele, and the administrations of the Departments of Pharmaceutical and Medicinal Chemistry, as well as those of Pharmaceutical Microbiology and Biotechnology of the Olabisi Onabanjo University, Sagamu, Nigeria for laboratory support. Also, we thank the Forest Research Institute of Nigeria (FRIN), Ibadan, Nigeria for authentication of the plant samples.

\section{FUNDING:}

The authors received no funding for the study.

\section{CONFLICTS OF INTEREST}

The authors declare no conflict of interest.

\section{References}

1. Bibcode, V.R. Sci. 190.....880s 1975. Available online: http//adsabs.harvard.edu/abs/ 1975sci....190_...8805 (accessed 10 February, 2018).

2. Ozusaglam, M.A.and Karakoca, K. 2013. Antimicrobial and antioxidant activities of Momordica charantia from Turkey. Afr. J. Biotechnol. 12, 1548-1558

3. Tadić, V., Oliva, A., Božović, M., Cipolla, A., De Angelis, M., Vullo, V., Garzoli, S. Vand Ragno, R. 2017. Chemical and Antimicrobial Analyses of Sideritis romana L. subsp. purpurea (Tal. ex Benth.) Heywood, an Endemic of the Western Balkan. Molecules 22, 1395.

4. Farombi, E.O. 2003. African indigenous plants with chemotherapeutic potentials and biotechnological approach to the production of bioactive prophylactic agents. Afr. $J$. Biotechnol. 2, 662-671

5. Shinwari, M.I. and Khan, M.A. 1998. Indigenous use of medicinal trees and shrubs of Margalla hills national park Islamabad. Pak. J. For. 48, 63-90.

6. World Health Organisation (WHO). WHO Tuberculosis Fact Sheet. 2002. No. 104. Available online: htpp://www.who. int/inf-fs/en/fact 104.html (accessed 10 February, 2018)
7. Roca, I., Akova, M., Baquero, F., Carlet, J., Cavaleri, M.,Coenen, S., Cohen, J.,Findlay, D., Gyssens, I.,Heure, O.E., Kahlmeter, G., Kruse, H., Laxminarayan, R., Liébana, E., López-Cerero, L.,MacGowan, A.,Martins, M., RodríguezBaño, J.,Rolain, J-M., Segovia, C., Sigauque, B.,Taconelli, E., Wellington, E. and Vila, J. 2015.The global threat of antimicrobial resistance: science for intervention New Microbes New Infect. 6, 22-29.

8. World Health Organization (WHO). Antibiotic Resistance. 2018. available online: http://www.who.int/news-room/ factsheets/detail/antimicrobial-resistance. (assessed 20 May, 2018),

9. Saki, K., Bahmani, M. and Rafieian-Kopaei, M. 2014.The effect of most important medicinal plants on two important psychiatric disorders (anxiety and depression)-a review. Asian Pac. J. Trop. Med. 7(Suppl 1). S34-S42.

10. Holetz, F.B., Ueda-Nakamura, T., Filho, B.P.D., Cortez, D.A.G., Morgado-díaz, J.A. and Nakamura, C.V. 2003. Effects of Essential oil of Ocimum gratissimum on the Trypanosomatid. Herpetomonas samuelpessoai. Acta Protozoologica, 42, 269-276.

11. Taylor, L. 2002. Technical report for Bitter lemon (Momordica charantia), In: Herbal Secrets of the Rainforest, 2nd ed., Sage Press Inc., Austin Texas USA, pp. 1-103.

12. Grover, J.K. and Yadav, S.P. 2004. Pharmacological actions and potential uses of Momordica charantia: a review. $J$. Ethnopharmacol. 93, 123-132.

13. Semiz, A. and Sen, A. 2007. Antioxidant and chemoprotective properties of Momordica charantia L. (bitter melon) fruit extract. Afr. J. Biotechnol. 6, 273-277.

14. Budrat, P. and Shotipruk, A. 2009. Enhanced recovery of phenolic compounds from bitter melon (Momordica charantia) by subcritical water extraction. Sep. Purif. Technol. 66, 125-129.

15. Luetrakul, T. 1998. Isolation and characterization of biologically active $30 \mathrm{kDa}$ proteins from the seed of Momordica charantia L. cultivated in Thailand. Pharmacy Thesis, Faculty of Graduate Studies,Mahidol University, Bangkok.

16. Chanchai, M. 2003. Analysis of charantin from Momordica charantia L. M.Sc. Thesis, Faculty of Graduate Studies, Mahidol University, Bangkok.

17. Akinremi, A.A., Omobuwajo, O.R. and Elujoba, A.A. 2000. Pharmacological Standards for Fruits of Cassia Fistula and Cassia podocarpa. Nig. J. Nat. Prod. Med. 4, 23-27.

18. Bakare, K.M. 1998. Literature Review on Phytochemical Studies of Cassia alata B. Tech. Dissertation (unpublished). Department of Pure and Applied Chemistry, LAUTECH, Ogbomosho, Nigeria.

19. Dalziel, J.M. 1937. Useful Plant of West Tropical Africa, The Crown Agents for the Colonies, London. pp. 49-188. 
20. Blot, S., Depuydt, P., Vogelaers, D., Decruyenaere, J., De Waele, J.,Hoste, E.,Peleman, R., Claeys, G., Verschraegen, G., Colardyn, F. and Vandewoude, K. 2005. Colonization Status and Appropriate antibiotic therapy for nosocomial bacteraemia caused by antibiotic-resistant gram-negative bacteria in an intensive care unit. Infect. Control Hosp. Epidemiol. 26, 575-579.

21. Todar, K. 2008. "Staphylococcus aureus and Staphylococcal disease"Online Textbook of Bacteriology. University of Wisconsin-Madison. available online: www. textbook of bacteriology.net. (Accessed 20 February, 2019).

22. Igbokwe, C.O., Lawal, T.O., Olorunnipa, T.A., Adeniyi, B.A. and Mahady, G.B. 2014. Antimicrobial susceptibility of crude extracts of Alliumas colonicum Linn (Whole Plant) and Gladiolus psittacinus Hook (Corm) against five common pathogens; An in vitro Investigation. Intl. J. Microbiol. Res. 6, 510-514.

23. Hagiwara, S., Murata, M., Aoki, M., Kaneko, M. and Oshima, K. 2013. Septic shock caused by Klebsiella oxytoca: An autopsy case and a survival case with driving extracorporeal Membrane oxygenation. Hippokratia 17, 171173.

24. Rhee, K.J., Sethupathi, P., Driks, A., Lanning, D.K. and Knight, K.L. 2004. Role of Commensal bacteria in development of gut-associated lymphoid tissue and preimmune antibody repertoire. J. Immunol. 172, 1118-1124.

25. Lockhart, S.R., Abramson, M.A., Beckmann, S.E.,Gallagher, G., Riedel, S., Diekema, D.J.; Quinn, J.P.and Doern, G.V. 2004. Antimicrobial resistance among Gram-negative bacillus causing infections in intensive care unit patients in the United States between 1993 and 2004. J. Clin. Microbiol. 45, 3352-3359

26. Campbell, C.K. 1994. Forms of aspergillosis. In The Genu Aspergillus, Edited by K.A. Powell, A. Renwick and J.F. Peberdy. New York: Plenum. pp. 313-320,

27. Denning, D.W. 1998. Invasive aspergillosis. Clin. Infect. Dis. 26, 781-803.

28. Morgan, J., Wannemuehler, K.A., Marr, K.A., Hadley, S., Kontoyiannis, D.P., Welsh, T.J., Fridkin, S.K., Pappas, P.G. and Warnock, D.W.2005.Incidence of invasive aspergillosis following hematopoietic stem cell and solid organ transplantation: interim results of a prospective multicentre surveillance program. Med. Mycol. $\mathbf{4 3}$ (Suppl. 1), S49-S58.

29. Abarca, M., Bragulat, M., Castella, G. and Cabaries, F. 1994."Ochratoxin A. Production by strains of Aspergillus nisger var. niger" Appl. Environ. Microbiol. 60, 2650-2652.

30. Ajayi, I.A. and Ojelere, O. 2014. Evaluation of the antimicrobial properties of the ethanolic extracts of some medicinal plant seeds from South-West Nigeria. J. Pharm. Biol. Sci. 9, 80-85.

31. Adejumo, O.E. and Ajayi, I.A. 2009. Phytochemical and elemental analysis of some Nigerian herbal plants with known diarrhoea properties, Intl. J. Chem. 19, 25-30.

32. Trease, G.E. and Evans, W.C. 1983. Textbook of Pharmacognosy $12^{\text {th }}$ Edn, Bailliere Tindall Ltd., London, pp. 60-61.
33. Harborne, J.B. 1998. Textbook of Phytochemical Methods. A Guide to Modern Techniques of Plant Analysis. $5^{\text {th }}$ Edition, Chapman and Hall Ltd., London, UK, pp. 21-72.

34. Adeniyi, B.A., Lawal, T.O. and Olaleye, S.B. 2006. Antimicrobial and gastroprotective activities of Eucalyptus camaldulensis crude extract J. Biol. Sci.6, 1141-1145.

35. Adeniyi, B.A.C., Lawal, T.O. and Mahady, G.B. 2009.In vitro susceptibility of Helicobacter pylori to extracts of Eucalyptus camaldulensis and Eucalyptus torelliana. Pharmaceut. Biol. 47, 99-102.

36. Martin, J.S. and Martin, M.M. 1982.Tannin assays in ecological studies: Lack of correlation between phenolics, proanthocyanidins and protein-precipitating constituents in mature foliage of six oak species. Oecologia. 54, 205-211.

37. Sultana, M., Verma, P.K., Raina, R., Prawez, S. and Dar, M.A. 2012 .Quantitative analysis of total phenolic, flavonoids and tannin contents in acetone and n-hexane extracts of Ageratumconyzoides. Int. J. Chem. Tech. Res. 4, 996-999.

38. Han, X., Shen, T. and Lou, H. 2007. Dietary polyphenols and their biological significance. Int. J. Mol. Sci. 8, 950-988.

39. El-Mahmood, A.M. and Doughari, J.H. 2008. Phytochemical screening and antibacterial evaluation of the leaf and root extracts of Cassia alata Linn. Afri. J. Pharm. Pharmacol. 2, 124-129.

40. Ehiowemwenguan, G.I., Inetianbor, J.E. and Yakubu, J.M. 2014. Antimicrobial Qualities of Senna alata. J. Pharm. Biol. Sci. 9, 47-52.

41. Panichayupakaranant, P.,Sakunpak, A. and Sakunphueak, A. 2009. Quantitative HPLC determination and extraction of anthraquinones in Senna alata leaves. J. Chromatogr. Sci. 47, 197-200.

42. Costa, J.G.M., Nascimento, E.M.M., Campos, A.R. and Rodrigues, F.F.G. 2011.Antibacterial activity of Momordica charantia (Cucurbitaceae) extracts and fractions. J. Basic Clin. Pharm. 2, 45-51

43. Omoregbe, R.E., Ikuebe, O.M. and Ihimire, I.G. 1996. Antimicrobial activity of some medicinal plants extracts on Escherichia coli, Salmonella paratyphi and Shigella dysenteriae. Afr. J. Med. Med Sci. 25, 373-5

44. Derrida, M. 2003. What is bitter melon (Momordica charantia)? available online: http://www.brama.com/ business/message/40688.html (accessed 10 February, 2018)

45. Michael, A. 1990.The science of dosage form design. $1^{\text {st }}$ Edition. Published by ELBS, pp. 426, 440-448 and 492.

46. Sun, J., Nagendra, P.K., Amin, I., Yang, B., You, X. and Li, L. 2013. Polyphenols: Chemistry, Dietary Sources and Health Benefits, Nova Science Publishers: New York, NY, USA. pp. 13-14.

47. Soobrattee, M.A., Neergheen, V.S., Luximon-ramma, A., Aruoma, O.I. and Bahorun, T. 2005. Phenolics as potential antioxidant therapeutic agents: Mechanism and actions. Mutat. Res. 579, 200-213.

48. Perumal, S. and Sellamuthu, M. 2007.The antioxidant activity and free radical-scavenging capacity of dietary phenolic extracts from horse gram (Macrotyloma uniflorum (Lam.) Verdc.) seeds. Food Chem. 105, 950-958. 
49. Rauha, J.P., Remes, S., Heinonen, M., Hopia, A., Kahkonen, M., Kujala, T.,Pihlaja, K., Vuorela, H. and Vuorela, P.2000.Antimicrobial effects of Finnish plant extracts containing flavonoids and other phenolic compounds. Int. J. Food Microbiol. 56, 3-12.

50. Kim, J.H., Park, E.S., Shim, J.H., Kim, M.N., Moon, W.S.,Chung, K.-H. and Yoon, J.-S. 2004. Antimicrobial activity of p-hydroxyphenyl acrylate derivatives. J. Agric. Food Chem. 52, 7480-7483,

51. Sagdic, O., Aksoy, A., Ozkan, G., Ekici, L. and Albayrak, S. 2008. Biological activities of the extracts of two endemic Sideritis species in Turkey. Innov. Food Sci. Emerg. Technol. 9, 80-84.

52. Kostadinova, E., Alipieva, K., Stefova, M., Antonova, D., Evstatieva, L., Stefkov, G., Tsvetkova, I., Naydenski, H. and Bankova, V.2008. Influence of cultivation on the chemical composition and antimicrobial activity of Sideritis spp. Pharmacogn. Mag. 4, 102-106.
53. Hayek, S.A., Gyawali, R. and Ibrahim, S.A. 2013. Antimicrobial natural products. In Microbial Pathogens and Strategies for Combating Them: Science, Technology and Education; Mendez-Vilas, A., Ed.; Formatex Research Center: Badajoz, Spain, Vol 2, pp. 910-921.

54. Sharifi-Rad, J., Salehi, B., Stojanovi'c-Radi'c, Z.Z., Fokou, P.V.T., Sharifi-Rad, M., Mahady, G.B., Sharifi-Rad, M., Masjedi, M.R., Lawal, T.O., Ayatollahi, S.A.,Masjedi, J., Sharifi-Rad, R., Setzer, W.N., Sharifi-Rad, M., Kobarfard, F., Rahman, A.U., Choudhary, M.I., Ata, A. andIriti, M. 2017. Medicinal plants used in the treatment of tuberculosisEthnobotanical and ethnopharmacological approaches. Biotechnol. Adv. S0734-9750(17)30077-0.

55. Odugbemi,T. A 2008. Textbook of Medicinal Plants from Nigeria, edited by Tolu Odugbemi, University of Lagos Press. Available online: http./www.medicinalplantsinnigeria. com (accessed 14 June, 2018). 